\title{
Assessment of Hazardous Volatile Organic Compounds (VOC) in a Residential Area abutting a Large Petrochemical Complex
}

\author{
S. Mohan ${ }^{1}$, R. Ethirajan* ${ }^{1}$, \\ ${ }^{1}$ Department of Civil Engineering, Indian Institute of Technology, Madras, Chennai 600036, India \\ Date Received: 27-09-2011Ｄate Accepted: 22-02-2012
}

\begin{abstract}
The results of VOC monitoring in a residential area abutting a petrochemical complex and the influence of causative parameters on the concentration is discussed in this paper. The monitored data reveals that about 21 hazardous VOC are predominantly present in the study area. Toluene is the most abundant compound of all. The mean concentration of benzene, a known carcinogen, is $38 \mu \mathrm{g} / \mathrm{m}^{3}$. The wide variation in toluene to benzene ratio $(\mathrm{T} / \mathrm{B})$ and the weak correlation between the concentration of various compounds and NOx indicate that they are contributed by multiple sources. There is no fixed pattern observed in the concentration variation between morning and evening samples. The BTEX ratio observed in this study varies from $1: 2.6: 0.3: 0.2$ to $1: 9.5 ; 2.1: 1.4$. The study reveals that the hazardous VOC in the study area are contributed by multiple sources and that the concentration of some of them is very high.
\end{abstract}

Keywords: Hazardous VOC, petroleum refinery, BTEX ratio, multiple sources, meteorology, open burning

\section{Introduction}

The volatile organic compounds (VOC) in the atmosphere can be broadly classified into two types; one that is having significant direct risk to human health and ecosystem and the other that take part in the complex photochemical reaction leading to the formation of high amounts of troposphere ozone, Peroxyacyl Nitrates (PAN) and other oxidants in urban areas (Colbeck and Mackenzie, 1994; Brown et al., 2007; Liu et al., 2008; Wang and Zhao, 2008; Parra et al., 2009). Petroleum refineries, petrochemical industries, automobiles, combustion of fossil fuels and biomass, use of solvents and marketing of petroleum products are major sources of VOC in urban environment (Jorquera and Rappengluck, 2004; Kansal, 2009). Many earlier studies reported that the VOC emission from petroleum refineries and petrochemical industries are hazardous in nature and pose serious risk to human health and that these industries heavily influence the concentration of ambient VOC in the vicinity (Badol et al., 2008; Nguyen et al., 2009). Comprehensive monitoring of ambient VOC to quantify their ambient concentrations, to identify their emission sources and to assess contribution levels of various sources is essential for developing strategies for management of VOC (Environment Australia, 2006; Wang and Zhao, 2008). These studies had also assessed the benzene, toluene, ethylbenzene and xylene (BTEX) ratios and toluene to benzene (T/B) ratio and used them to assess the contributing sources.

\footnotetext{
*Corresponding author: E-mail-rnethirajan@gmail.com

Tel-++ 919444119155 , Fax- ++ 941125672540

ISSN 2235-9370 Print / ISSN 2235-9362 Online (C2012 University of Sri Jayewardenepura
} 
Studies had also monitored the diurnal and seasonal variations of the concentration of various compounds. Quantity of highly reactive species usually decrease in daylight time due to photochemical reactions, but the quantity of relatively less reactive species gradually increases due to accumulation. Wang and Zhao (2008) assessed ambient volatile organic compounds near major roads in urban Nanjing, China and found that the toluene-to-benzene ratios were 4.4 and 3.8 in the first and the second sampling campaign, respectively. Liu et al. (2008), while monitoring the ambient VOC in an industrial city of southern Taiwan found that toluene, isopentane, ethylbenzene, and benzene were the most abundant species with high T/B ratios $(7.56-14.25)$ and concluded that the higher ratio was due to impact from industries and mobile emissions. It was also observed in this study that the small $\mathrm{X} / \mathrm{B}$ and $\mathrm{X} / \mathrm{E}(0.38-0.65)$ both revealed the fact that photochemical reactions were active.

In urban areas, especially in cities where petroleum refineries and petrochemical industries are located, a large population of people are exposed to high levels of toxic and hazardous VOC. Poverty and improper town planning force a large number of people to live close to the potential sources like petrochemical complexes. Regular monitoring of hazardous VOC in the ambient air is not carried out in many countries. Hence, there is no or very limited information is available on the prevailing concentration of predominant hazardous VOC in the atmosphere. Even with the available information, the enforcing agencies are struggling hard to evolve strategies for the management of these VOC due to difficulties in identifying contributing sources and their contribution levels. In countries like India this problem is more complex as profiles of VOC emission from various potential contributing sources are also not available.

The main objective of the reported work was to assess the levels of hazardous VOC present in the typical identified area and to establish a relationship between their concentration and their causative parameters. This paper discusses the results of monitoring of hazardous VOC at Manali near Chennai, a South Indian metropolitan city, where a large petrochemical industrial complex is located. The identification of predominantly present compounds and their concentration variation with respect to possible influencing parameters are the major aspects discussed in this paper.

\section{Study Area}

\subsection{Geographical Details}

Chennai is the fourth largest city in India located on its east coast. The total area of the city is $174 \mathrm{~km} 2$. A $13 \mathrm{~km}$ long beach, the second longest beach in the world is one of the significant features of the city. A petrochemical industrial complex is located on its outskirt on the northern side at a place called Manali. This complex has a major petroleum refinery, surrounded by more than 15 large scale petrochemical industries. The emissions from these industries affect the quality of ambient air in the city. In addition to these industries there are about 25 lakh vehicle plying on the Chennai roads every day. Chennai Corporation is dumping more than 50\% (about $1500 \mathrm{~T} / \mathrm{d}$ ) of the total unsegregated solid wastes generated in the city in a huge area at Kodungaiyur near Manali industrial complex. The municipal solid waste dumping yard of Manali municipality lies in between these large petrochemical industries. Open burning of solid wastes takes place round the clock in all these dump yards resulting in contribution of several hazardous air pollutants to the ambient air. In addition to these sources, there are large scale sewage and industrial effluent treatment plants located in and around this area. Thus, it can be seen that this location is highly susceptible to the exposure of various hazardous air pollutants. The location of the study area is shown in Figure 1.

\subsection{Meteorological Details}

The mean winter temperature of Chennai is $30 \mathrm{oC}$ and the mean summer temperature is $35^{\circ} \mathrm{C}$. The maximum ambient temperature is as high as $43^{\circ} \mathrm{C}$ during hottest months of April and May. October to December is the monsoon period with average rainfall of $1100 \mathrm{~mm} /$ year. The wind pattern in Chennai 
is unique. South-west winds are predominant for about 7 months in a year between March and September. The north-east winds are common during October to February. However, being a coastal city there is a major diurnal variation in wind direction and wind speed in Chennai. Even during southwest wind season a substantial part of the day may experience easterly or north-easterly winds.

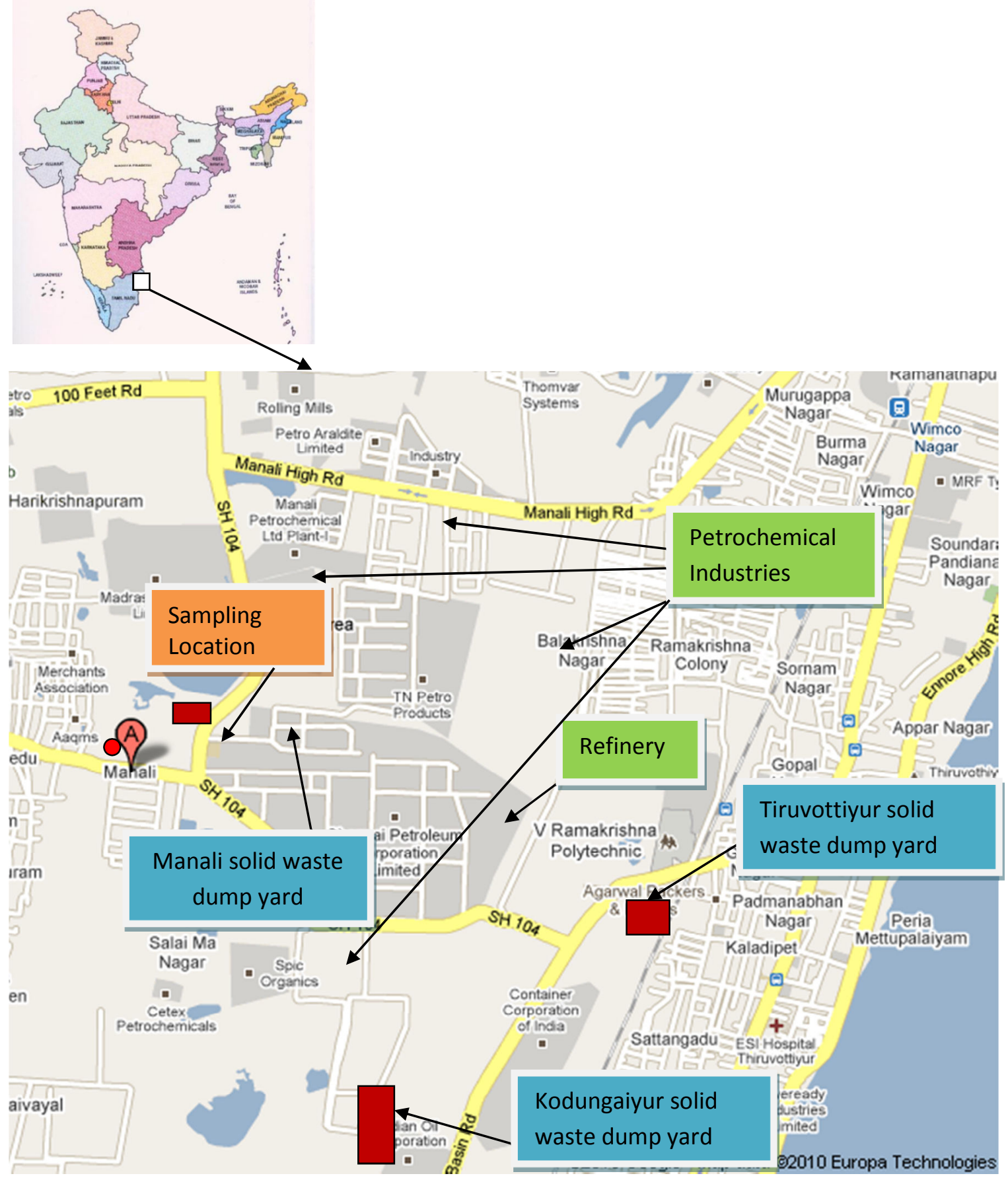

Figure 1: Manali Petrochemical Industrial Complex

\subsection{Contributing Sources}

VOC are contributed by almost all the sources of air pollution. Petroleum refineries and petrochemical industries are the major sources of VOC in the areas where these industries are located (Liu et al., 2008; Wang and Zhao, 2008; Parra et al., 2009). Several studies reveal that automobiles are significant contributors in non-industrialized urban areas (Nguyen et al., 2009; Parra et al., 2009). 
Kansal (2009) reported that biomass burning contributes to about $45 \%$ of the total VOC emitted by anthropogenic sources on the earth. Wastewater treatment plants also emit large amount of VOC (Cheng et al., 2008). Hence, a detailed assessment of various emission sources of VOC in the selected study area was carried out. The significant industrial sources that were identified are listed in Table 1. The details about other significant sources such as automobiles, open burning of un-segregated garbage and biomass, waste disposal sites, fuel distribution centers were also collected. It was identified from this assessment that the following five major source types are contributing to the ambient VOC concentration in the study area; Petroleum refinery, Petrochemical industries, Sewage and industrial wastewater treatment plants, Open dumping and burning of solid wastes and Automobiles.

Table1: Details of Significant Industrial Sources of VOC at Manali

\begin{tabular}{|c|c|c|c|}
\hline S1 No & Type of Industry & Raw Materials & Product \\
\hline 1 & $\begin{array}{l}\text { Petroleum Refinery - } \\
1 \text { No }\end{array}$ & Crude Oil & $\begin{array}{l}\text { Petroleum products like LPG, } \\
\text { Naphtha, MS, Diesel, SKO, } \\
\text { Lube oil, Wax, Hexane, FO }\end{array}$ \\
\hline 2 & $\begin{array}{l}\text { Fertilizer Industry }-2 \\
\text { Nos. }\end{array}$ & $\begin{array}{l}\text { Naphtha } \\
\text { Phosphoric Acid } \\
\text { Potash }\end{array}$ & $\begin{array}{l}\text { Urea } \\
\text { NPK }\end{array}$ \\
\hline 3 & $\begin{array}{l}\text { Petrochemical } \\
\text { Industries } \\
-13 \text { Nos. }\end{array}$ & $\begin{array}{l}\text { Propylene, Chlorine, Lime, } \\
\text { Kerosene, Benzene, Methanol, } \\
\text { Terepthalic Acid, Mono Ethylene } \\
\text { Glycol, Mono Propylene Glycol, } \\
\text { Pure Isopthalic Acid, Alkyl Phenol, } \\
\text { Sulphur, Naphthalene, Sulphuric } \\
\text { Acid, Formaldehyde, Caprolactum, } \\
\text { LPG, Aluminum Trichloride, } \\
\text { Epichlorohydrin, Bisphenol-A, } \\
\text { Sodium Hydroxide, Hydro } \\
\text { Choleric Acid, Polyamides. }\end{array}$ & $\begin{array}{l}\text { Epichlorohydrin, Linear Alkyl } \\
\text { Benzene, Propylene Oxide, } \\
\text { Propylene Glycol, Polyol, } \\
\text { Polyester, PET, Lube oil } \\
\text { additives, Syntan, Synthetic fat } \\
\text { liquor, Grease \& Lubricants, } \\
\text { Nylon tyre card fabric \& yarn, } \\
\text { Poly butylenes, Epoxy Resin, } \\
\text { Methyl Ethyl Ketone }\end{array}$ \\
\hline
\end{tabular}

\subsection{Sampling and Analysis}

As monitoring and assessment of the ambient concentration of various hazardous VOC present in the study area had not been done prior to this study, it was monitored as a part of this study. Manali Police Station situated at Manali residential area was identified as sampling location. All samples were collected from this location. The sampling and analysis were carried out as per the procedures laid down in US EPA compendium method TO-17 (US EPA, 1997). As the study area is dominated by industrial sources, emphasis was given to the assessment of VOC that are more hazardous. The ambient air samples were collected in standard adsorption tubes of Marks International Ltd with $3.67 \mathrm{~mm}$ ID and $128.02 \mathrm{~mm}$ length. The tube contains tenex and carbopack B in the ratio of $125 \mathrm{mg}$ to $75 \mathrm{mg}$. The SKC make low volume sampler (Model No. SKC/224/PCXR8) was used to draw air through these adsorption tubes (Kuntasal et al., 2005; Ras et al., 2008). Most of the samples were collected with an air flow rate of about $84 \mathrm{ml} / \mathrm{min}$ for two hours resulting in collection of pollutants from about $10 \mathrm{~L}$ of air (Borrego et al., 2006, Hellen et al., 2006). However, simultaneous samples were also collected with different flow rates and for different durations to assess the influence of these parameters in sampling. Samples were collected between 8 a.m. and 10 a.m. in the morning and 4 p.m. and 6 p.m. in the evening as per this protocol (Hellen et al., 2003). Some samples were also collected in the night between 10 p.m. and 12 Midnight. A total of 50 samples (23 samples during weekdays and 27 samples during weekends/holidays) were collected between July 2008 and October 2009. The sample tubes were thermally desorbed to release the pollutants and the pollutants were analysed in GC-MS. 
The adsorption tubes were desorbed at $250^{\circ} \mathrm{C}$ for $10 \mathrm{~min}$. The pollutants from the thermal desorption were collected in a secondary trap at $10^{\circ} \mathrm{C}$. The secondary trap was then rapidly heated to $300^{\circ} \mathrm{C}$ to release all the pollutants to the GC column. A column of $60 \mathrm{~m}$ length, $0.25 \mathrm{~mm}$ ID and 4 micron thickness solid coating of Varian make was used. MS detector (Scan mode) of Agilent Technologies make (Model No. 6890N/5973inat) was used to detect and quantify the pollutants (Parra et al., 2009). The initial temperature of the column was $35^{\circ} \mathrm{C}$ for $3 \mathrm{~min}$. The temperature of the column was raised at the rate of $8^{\circ} \mathrm{C} / \mathrm{min}$ up to $90^{\circ} \mathrm{C}$. After $2 \mathrm{~min}$ at $90^{\circ} \mathrm{C}$, the temperature was raised at the rate of $6^{\circ} \mathrm{C} / \mathrm{min}$ to $240^{\circ} \mathrm{C}$. The total run time of the sample was $40 \mathrm{~min}$ (Harrison and Roger 1986; Ribes et al., 2007). All the detected compounds were identified using NIFT library. Compounds listed under 60 target compound list of US EPA were quantified using appropriate standard.

\section{Results and Discussion}

\subsection{Compounds and concentrations}

Several studies have reported that hundreds of different compounds were detected when monitoring VOC in urban areas (Wang and Zhao, 2008; Nguyen et al., 2009). In this study, about 40 different volatile organic compounds were detected in all the samples that were analysed and more than 100 different compounds were detected in some of the samples. Out of these compounds, the compounds that are listed under 60 target compound list of US EPA were quantified using appropriate standard. Among these 60 compounds, about 21 hazardous volatile organic compounds were predominantly present in all the samples. The maximum, minimum and mean concentrations of all these 21 compounds are listed in Table 2.

Table 2: Observed concentrations of different VOC

\begin{tabular}{llrrr}
\hline \multirow{2}{*}{ SI. No } & Compounds & \multicolumn{2}{c}{ Concentration in $\mu \mathrm{g} / \mathrm{m}^{3}$} & Maximum \\
\cline { 3 - 5 } & Benzene & 83.25 & 13.24 & 38.23 \\
2 & Toluene & 352.58 & 49.87 & 156.14 \\
3 & Ethylbenzene & 61.40 & 5.43 & 27.37 \\
4 & m,p-Xylene & 59.52 & 3.97 & 26.80 \\
5 & o-Xylene & 54.52 & 2.29 & 22.94 \\
6 & 1,2-Dichloropropane & 59.16 & 0.00 & 13.71 \\
7 & Trichloroethylene & 13.65 & 0.10 & 4.59 \\
8 & Styrene & 22.00 & 1.00 & 6.31 \\
9 & 1,3,5-Trimethylbenzene & 27.20 & 0.41 & 7.22 \\
10 & 1,2,4-Trimethylbenzene & 12.25 & 0.42 & 4.67 \\
11 & Naphthalene & 23.56 & 0.43 & 7.04 \\
12 & Isopropylbenzene & 5.27 & 0.00 & 1.31 \\
13 & n-Propylbenzene & 9.51 & 0.10 & 2.97 \\
14 & Carbon Tetrachloride & 23.96 & 0.00 & 7.75 \\
15 & 1,4-Dichlorobenzene & 18.35 & 0.00 & 4.33 \\
16 & Secbutylbenzene & 3.32 & 0.00 & 0.34 \\
17 & 4-Isopropyltolune & 13.17 & 0.00 & 1.76 \\
18 & Butylbenzene & 6.32 & 0.00 & 0.42 \\
19 & Chloroform & 19.01 & 0.00 & 20.21 \\
20 & 1,2-Dichloroethane & 84.16 & 0.00 & 9.50 \\
21 & Trichlorofluoromethane & 0.92 & 0.00 & 0.04 \\
\hline
\end{tabular}


Toluene is the most abundant compound of all with concentration ranging from $50 \mu \mathrm{g} / \mathrm{m}^{3}$ to 350 $\mu \mathrm{g} / \mathrm{m}^{3}$. Concentration of toluene observed in similar studies were not so high as observed in this study even though toluene was also found to be most abundant compound in all the studies (Guo et al., 2004; Nguyen et al., 2009). World Health Organization (WHO) recommended a maximum of $260 \mu \mathrm{g} / \mathrm{m}^{3}$ of toluene averaged over a week as a limiting value or the protection of human health from toluene (Parra et al., 2009). The toluene concentration in about $10 \%$ of samples exceeds $260 \mu \mathrm{g} / \mathrm{m}^{3}$. The mean concentration of Benzene, a known carcinogen (WHO, 2000) is $38 \mu \mathrm{g} / \mathrm{m}^{3}$. Benzene is the only VOC for which standard has been prescribed in the new National Ambient Air Quality Standards of India as $5 \mu \mathrm{g} / \mathrm{m}^{3}$. Benzene concentration exceeds this level in almost all the samples (Figure 2). The mean concentration of 1,2-dichloroethane, 1,4-dichlorobenzene, trichloroethylene, and chloroform is also high and not many monitoring studies had identified such a high concentration of halogenated VOC in the ambient air (Fernandez et al., 2004; Nguyen et al., 2009; Parra et al., 2009).

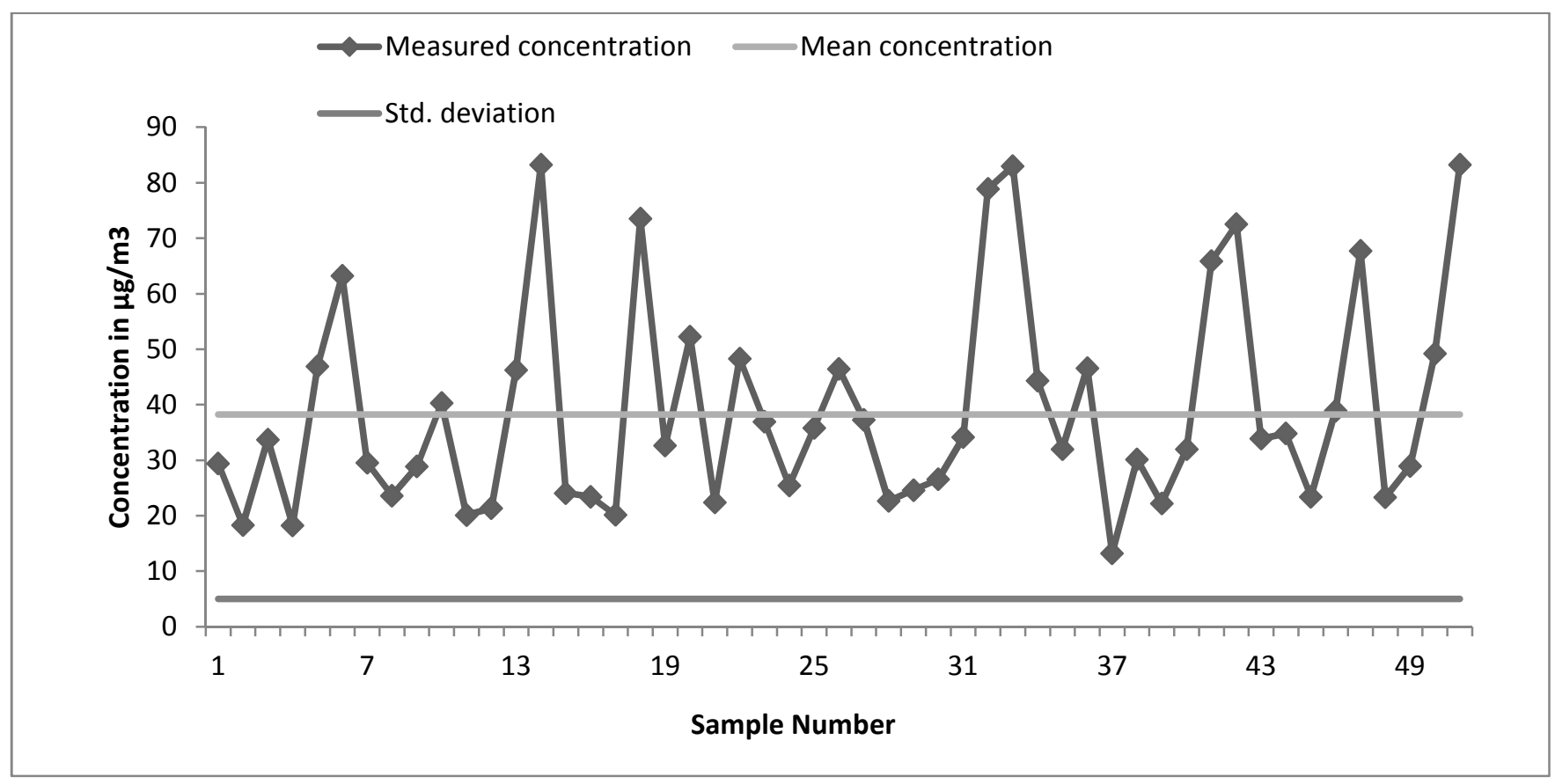

Figure 2: Variation of benzene concentration among different samples.

The analysis of variation in the concentration of pollutants in different samples indicates that there is no common trend between all the pollutants. However, a strong correlation exists between the concentrations of certain specific compounds. Benzene, toluene, ethylbenzene, m,p-xylene and o-xylene are strongly correlated with coefficients ranging between 0.70 and 0.90 similar to what was observed by Fernandez et al., (2004) and Buczynska et al. (2009). The concentrations of isopropylbenzene and npropylbenzene are also very well correlated with correlation coefficients of 0.8 . The variation in the concentration of carbon tetrachloride and trichloroethylene follow a common trend with correlation coefficient of 0.70. Naphthalene, 1, 2-dichloropropane, 1, 3, 5-trimethylbenzene are not having significant correlation with other compounds. It has been attempted to find if there is any correlation between the concentration of these compounds and NOx. It was found that NOx is not having any significant correlation with any of these compounds. Previous studies have indicated that there will be strong correlation between VOCs and NOx only when automobile is the major contributor (Fernandez et al., 2004; Lung et al., 2007; Parra et al., 2009). The above observations indicate that multiple source types are contributing to the concentration of these pollutants and that each source type contributes significantly to certain specific group of compounds. The study also reveals that automobile is not the major contributor of all the compounds. 


\subsection{Concentration Variation between Weekdays and Weekends}

It has been attempted to find whether there is any distinct difference in the concentration of any of the compounds between weekdays and weekends. The mean concentrations of various pollutants on weekdays and weekends are given in Table 3. The variation in the concentration of most of the compounds between weekdays and weekends is negligible. It clearly indicates that the emission of these compounds from most of the contributing sources is independent of the day of the week. The concentrations of ethylbenzene, m,p-xylene, and o-xylene are marginally higher on weekdays, which indicates that the automobile is one of the major contributors of these compounds (Lee et al., 2002; Fernandez et al., 2004). The higher concentration of some of the chlorinated compounds lime trichloroethylene, chloroform, 1, 2-dichloroethane etc. on weekends indicates the possibility of higher emissions from industries and commercial establishments due to maintenance and cleaning and also due to disturbance in power supply.

Table 3: Mean Concentration of Various Compounds on Weekdays and Weekends

\begin{tabular}{lrr} 
& \multicolumn{2}{c}{ Concentration in $\mu \mathrm{g} / \mathrm{m}^{3}$} \\
\cline { 2 - 3 } Compounds & Weekday & Weekend \\
\hline Benzene & 38.45 & 37.96 \\
Toluene & 151.94 & 161.07 \\
Ethylbenzene & 24.47 & 30.78 \\
$m, p$-Xylene & 25.70 & 28.09 \\
$o$-xylene & 22.17 & 23.85 \\
1,2-Dichloropropane & 14.76 & 12.48 \\
Trichloroethylene & 4.61 & 4.56 \\
Styrene & 6.25 & 6.39 \\
1,3,5-Trimethylbenzene & 7.50 & 6.89 \\
1,2,4-Trimethylbenzene & 4.12 & 5.32 \\
Naphthalene & 6.98 & 7.11 \\
Isopropylbenzene & 1.38 & 1.23 \\
n-Propylbenzene & 2.73 & 3.25 \\
Carbon Tetrachloride & 8.33 & 7.07 \\
1,4-Dichlorobenzene & 3.93 & 4.79 \\
Sec-butylbenzene & 0.36 & 0.30 \\
4,Isopropyltolune & 1.90 & 1.60 \\
Butylbenzene & 0.50 & 0.32 \\
Chloroform & 21.48 & 18.72 \\
1,2-Dichloroetahne & 13.29 & 5.04 \\
Trichlorofluoromethane & 0.06 & 0.01 \\
\hline
\end{tabular}

\subsection{Diurnal Variation in concentration}

There are certain contradictory observations made in different studies about the diurnal variation in the concentration. Parra et al. (2009) observed that the concentration of VOC is higher during morning compared to other times of the day, whereas Nguyen et al. (2009) observed that the concentration peaks occurred only during afternoon. Song et al., (2008) observed that the total VOC concentrations were higher at night than at day in Beijing due to stronger winds at day time. Parra et al. (2009) also observed that the VOC concentration during winter and autumn is higher due to atmospheric stability. The variation in the morning and evening concentration of the compounds is presented in Table 4. It can be seen from the Table 4 that the difference between the concentration of most of the compounds in the morning and evening samples is very less. The absence of fixed pattern in the 
concentration variation between morning and evening samples may be due to limited diurnal variation in the ambient temperature and due to dominance of emission from industries other contributing sources which operate round the clock. The minor variations, therefore, are mainly attributed to the wind direction and wind speed. Similar observation was also reported by Choi and Ehrman (2004) when they investigated the source of volatile organic carbon in the Baltimore, USA.

Table 4: Mean Concentration of Various Compounds during Morning and Evening

\begin{tabular}{lrr}
\hline & \multicolumn{3}{c}{ Concentration in $\mu \mathrm{g} / \mathrm{m}^{3}$} & \\
\cline { 2 - 3 } Compounds & Morning & Evening \\
\hline Benzene & 41.71 & 36.44 \\
Toluene & 153.50 & 161.28 \\
Ethylbenzene & 30.22 & 25.04 \\
$m, p$-Xylene & 27.70 & 26.22 \\
$o$-xylene & 23.78 & 22.56 \\
1,2-Dichloropropane & 15.10 & 13.65 \\
Trichloroethylene & 4.63 & 4.68 \\
Styrene & 6.48 & 6.27 \\
1,3,5-Trimethylbenzene & 8.22 & 6.69 \\
1,2,4-Trimethylbenzene & 5.20 & 4.35 \\
Naphthalene & 7.93 & 6.33 \\
Isopropylbenzene & 1.41 & 1.30 \\
n-Propylbenzene & 3.23 & 2.91 \\
Carbon Tetrachloride & 6.97 & 8.42 \\
1,4-Dichlorobenzene & 3.85 & 5.15 \\
Sec-butylbenzene & 0.36 & 0.26 \\
4,Isopropyltolune & 1.42 & 2.37 \\
Butylbenzene & 0.44 & 0.48 \\
Chloroform & 16.85 & 21.20 \\
1,2-Dichloroetahne & 9.50 & 10.60 \\
Trichlorofluoromethane & 0.07 & 0.02 \\
\hline
\end{tabular}

\subsection{BTEX Ratios}

Ratios between the concentrations of benzene, toluene, ethylbenzene and xylenes (BTEX ratio) are very important and useful information to infer the sources of ambient concentration of various VOCs. Several studies concluded about the number and type of contributing sources using toluene to benzene ratio (T/B). Higher T/B ratios indicate the presence of several contributing sources. The T/E, $\mathrm{B} / \mathrm{E}$ and $\mathrm{X} / \mathrm{E}$ ratios are useful tool to understand the photochemical age of the VOCs. However, there exists a vast variation between BTEX ratios observed in different studies. Lee et al., (2002) observed in his study that BTEX ratio could vary from $3: 4: 1: 4$ to $3: 14: 1: 28$. At locations where automobile is the only major contributing source, the toluene to benzene ratio (T/B) will be low, varying between 2 and 4 . The T/B ratio however could be as high as 40 at locations where several source types contribute these compounds (Lee et al., 2002; Buczynska et al., 2009).

The BTEX ratio observed in this study varies from 1:2.6:0.3:0.2 to 1:9.5:2.1:1.4. The toluene to benzene ratio $(\mathrm{T} / \mathrm{B})$ varies widely between 2.6 and 9.5 . This clearly indicates that there are multiple contributing sources to these compounds in the identified area. The mean T/B ratio is about 4.5 on both holidays on working days (Lee et al., 2002). The scatter plots between toluene/ethylbenzene (T/E) and toluene/m,p-xylene $(\mathrm{T} / \mathrm{X})$ is shown in Figure 3. Similarly the scatter plot between benzene/ethylbenzene $(\mathrm{B} / \mathrm{E})$ and benzene/m,p-xylene $(\mathrm{B} / \mathrm{X})$ is shown in Figure 4. The higher $\mathrm{R} 2$ value of the plot in Figure 3 than of the plot in Figure 4 indicates that toluene, ethylbenzene and xylenes are contributed by the same 
source and that their emission levels are uniform with respect to each other whereas vast variation exists in the emission level of benzene.

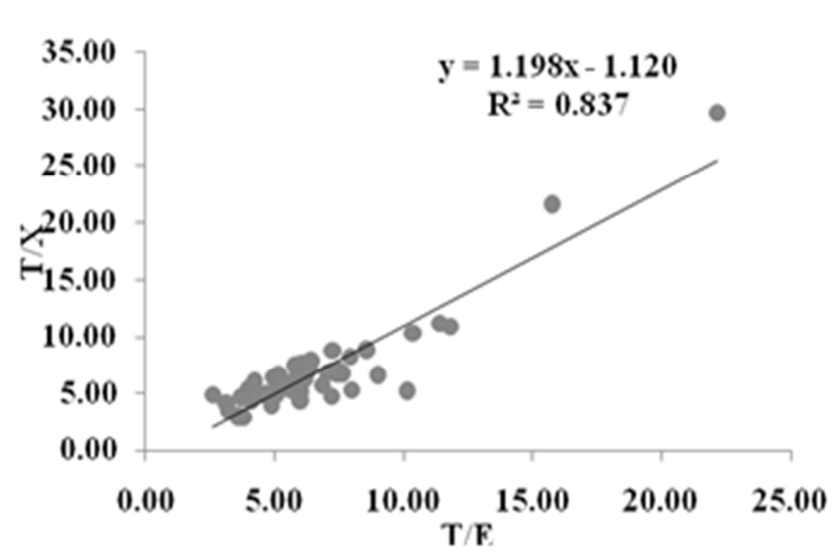

Figure 3: Scatter Plot of T/E vs T/X

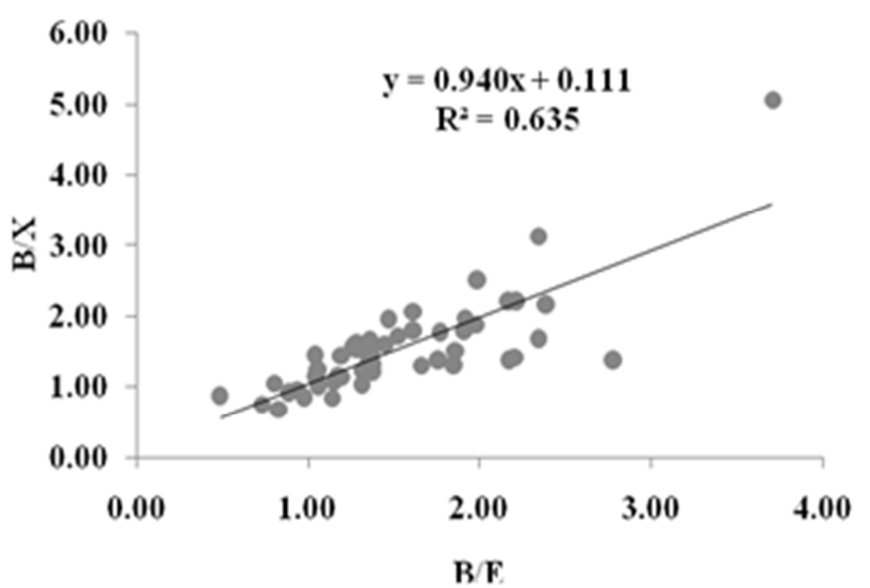

Figure 4: Scatter Plot of $\mathrm{B} / \mathrm{E}$ vs $\mathrm{B} / \mathrm{X}$

The variations of toluene to ethylbenzene $(\mathrm{T} / \mathrm{E})$, benzene to ethylbenzene $(\mathrm{B} / \mathrm{E})$ and $\mathrm{m}, \mathrm{p}$-xylene to ethylbenzene $(\mathrm{X} / \mathrm{E})$ ratios between summer and winter samples are shown in Figure 5. Ethylbenzene and xylene are more reactive than benzene and toluene and hence their concentration decreases quickly in the ambient air when the photochemical reaction takes place. The rate of photochemical reaction is higher in summer than in winter. It can be seen from Figure 5 that both $\mathrm{T} / \mathrm{E}$ and $\mathrm{B} / \mathrm{E}$ ratios are high in summer than in winter. There is very little variation in $\mathrm{X} / \mathrm{E}$ ratio between summer and winter. It indicates that the rate of photochemical reaction which reduces the concentration of ethylbenzene and $\mathrm{m}, \mathrm{p}$-xylene faster than the concentration of toluene and benzene is high in the area (Parra et al., 2009).

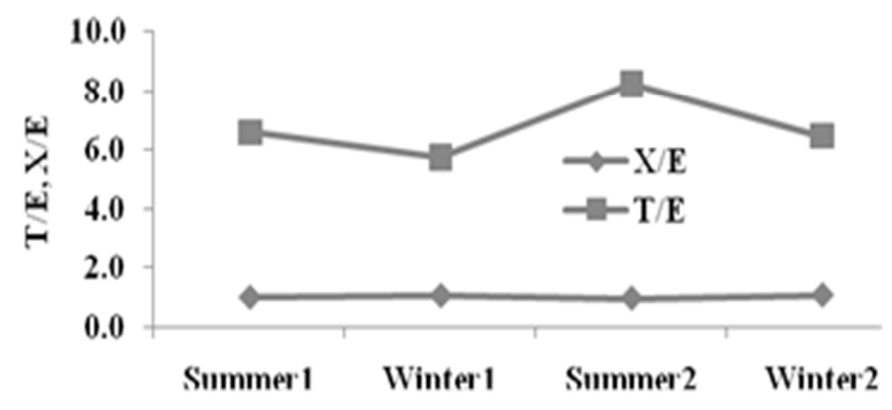

(a) $\mathrm{B} / \mathrm{E}$ and $\mathrm{X} / \mathrm{E}$

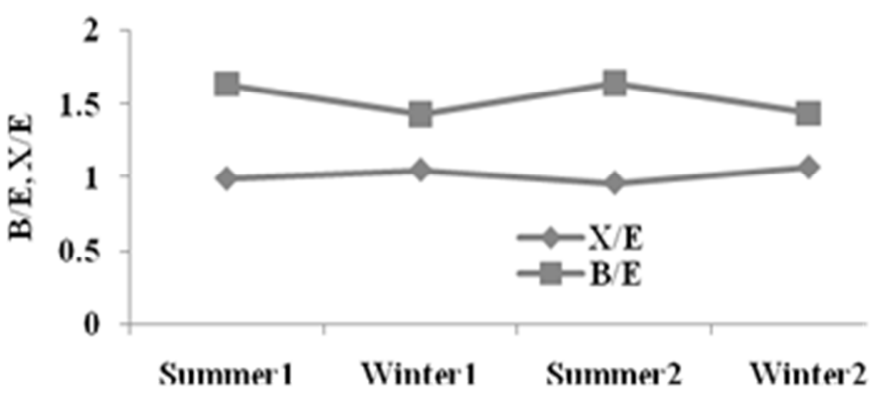

(b) $\mathrm{T} / \mathrm{E}$ and $\mathrm{X} / \mathrm{E}$

Figure 5: Variation of B/E, T/E and X/E Ratios for summer and winter Seasons

\subsection{Wind Direction and Concentration}

Wind direction and wind speed play an important role in the concentration of various pollutants (Choi and Ehrman 2004). To analyse the variation in concentration with respect to wind direction, the samples were grouped under three categories. The first one is a set of samples collected during wind direction between south-east and north-east (SE-NE), the direction in which most of the industries is located, including the refinery. Out 50 samples, 15 samples were collected during this wind direction. The second group contains samples collected during wind direction between south-west and south-east (SW-SE) and the third during wind direction between north and north-east (N-NE). SW-SE direction is 
marked by a mixed type of activities including industrial, commercial and residential and 22 samples were collected during this wind direction. There are only a few industries located in N-NE direction and 3 samples were collected during this period. The wind was calm while collecting 10 samples. The mean concentration of all the compounds in the samples under each of these groups has been compared to find out the pollutants that are predominant during different wind directions and presented in Table 5.

Table 5: Mean Concentration of Compounds during Different Wind Directions

\begin{tabular}{clrrrr}
\hline & & \multicolumn{3}{c}{ Concentration in $\mu \mathrm{g} / \mathrm{m}^{3}$} \\
\cline { 3 - 5 } S1. & & \multicolumn{3}{c}{ Wind direction } & \multirow{2}{*}{ Calm } \\
\cline { 3 - 5 } No. & & N-NE & SW-SE & SE-NE & \\
\cline { 3 - 5 } 1 & Benzene & 37.53 & 40.10 & 36.18 & 37.46 \\
2 & Toluene & 180.48 & 154.69 & 152.29 & 154.05 \\
3 & Ethylbenzene & 28.22 & 27.52 & 26.81 & 28.97 \\
4 & m,p-Xylene & 26.47 & 27.09 & 27.58 & 24.83 \\
5 & o-xylene & 25.78 & 24.18 & 22.03 & 21.61 \\
6 & 1,2-Dichloropropane & 15.13 & 13.02 & 13.02 & 15.30 \\
7 & Trichloroethylene & 5.69 & 4.62 & 3.63 & 5.75 \\
8 & Styrene & 8.95 & 5.86 & 6.54 & 7.86 \\
9 & 1,3,5-Trimethylbenzene & 7.40 & 6.36 & 7.02 & 9.30 \\
10 & 1,2,4-Trimethylbenzene & 4.41 & 6.14 & 4.68 & 3.49 \\
11 & Naphthalene & 5.47 & 6.55 & 6.63 & 10.99 \\
12 & Isopropylbenzene & 2.65 & 0.98 & 1.41 & 1.51 \\
13 & n-Propylbenzene & 4.19 & 3.24 & 2.81 & 2.97 \\
14 & Carbon Tetrachloride & 10.92 & 8.12 & 6.99 & 8.63 \\
15 & 1,4-Dichlorobenzene & 6.09 & 4.48 & 3.15 & 6.58 \\
16 & Secbutylbenzene & 0.14 & 0.26 & 0.15 & 0.59 \\
17 & 4Isopropyltolune & 0.92 & 1.82 & 2.18 & 1.93 \\
18 & Butylbenzene & 0.43 & 0.66 & 0.54 & 0.09 \\
19 & Chloroform & 15.38 & 21.88 & 21.26 & 30.74 \\
20 & 12dichloroetahne & 7.98 & 11.05 & 6.51 & 11.60 \\
21 & Trichlorofluoromethane & 0.31 & 0.01 & 0.03 & 0.03 \\
\hline
\end{tabular}

The mean concentration of benzene is higher during SW-SE winds, whereas the mean concentration of toluene is higher during N-NE winds. The mean concentration of both these compounds in the other three directions is almost the same. Significant presence of halogenated VOC during SE-NE winds, the direction in which sea is located indicates that sea is one of the sources of emission of certain halogenated VOC (Srivastava 2004). Continuous burning of solid waste at Manali solid waste dump yard, which is located very close to the sampling point could be the reason for higher concentration of naphthalene during calm condition. Except these minor variations, the mean concentration of most of the compounds are the same in all the wind directions indicating equal contribution from multiple contributing sources to the concentration of these compounds. It also indicates that refinery alone is not the major contributor of these compounds.

\section{Conclusions}

The study revealed that the concentration of some of the hazardous VOC are very high, high enough to cause significant health effects to the people living in the vicinity of this industrial complex. The higher T/B ratio clearly indicates that there are multiple sources contributing to the concentration of hazardous VOC in the study area. Though automobile is one of the contributors of these pollutants, the study revealed that the refinery and the petrochemical industries are major and significant contributors of many compounds. The study also revealed that some of the compounds are contributed by long 
distance sources. The vast differences in the concentration levels over the study duration suggest that there is no fixed pattern in the emission of these compounds. High correlation between the concentrations of certain compounds clearly indicates that they are emitted by distinct source types. The wind speed and wind direction are major factors in determining the concentration levels while the ambient temperature plays very less role as it is almost constant over the day and throughout the year. The major limitation of this study is its inability to identify the actual contributors and their contribution levels for each sample. As multiple sources are contributing, specific contributing sources and their exact contribution levels for various compounds in each sample have to be assessed using a suitable receptor model so as to develop strategies to manage the VOC level in this area.

\section{References}

Badol, C., Locage, N., Leonardis, T. and Galloo, J.C., 2008. Using a source-receptor approach to characterise VOC behavior in a French urban area influenced by industrial emissions. Part I: Study area description, data set acquisition and qualitative data analysis of the data set. Science of the Total Environment. 385: 441-452.

Borrego, C., Gomes, P., Barros, N. and Miranda, A.I., 2006. Importance of handling organic atmospheric pollutants for assessing air quality. Journal of Chromatography A. 889: 271-279.

Brown, S.G., Frankel, A. and Hafner, H.R., 2007. Source apportionment of VOCs in Los Angeles area using positive matrix factorization. Atmospheric Environment. 41: 227-237.

Buczynska, A.J., Krata, A., Stranger, M., Godoi, A.F.L., Kontozova-Deutsch, V., Bencs L., Naveau, I., Roekens, E. and Van G.R., 2009. Atmospheric BTEX-concentrations in an area with intensive street traffic. Atmospheric Environment. 43: 311-318.

Cheng, W.H., Hsu, S.K. and Chou, M.S., 2008. Volatile organic compound emissions from wastewater treatment plants in Taiwan: Legal regulations and cost control. Journal of Environmental Management. 88: 1485-1494.

Choi, Y.J. and Ehrman, S.H., 2004. Investigation of sources of volatile organic carbon in the Baltimore area using highly time-resolved measurements. Atmospheric Environment. 38: 775-791.

Colbeck, I. and Mackenzie, A.R., 1994. Air Pollution by Photochemical Oxidants, Elsvier, Amsterdam, The Netherlands.

Environment Australia, 2000. State of knowledge report: Air Toxics and Indoor Air Quality in Australia, Air Toxics Section, Canberra.

Fernandez, V.V., Lopez, M.P., Muniategu, S., Prada, R.D., Fernandez, F.E. and Tomas, X., 2004. $\mathrm{C}_{1}$ to $\mathrm{C}_{9}$ volatile organic compound measurements in urban air. Science of the Total Environment. 334335: 167-176.

Guo, H., Wang, T., Simpson, I.J., Blabe, D.R., Yu, X.M. and Kwok, Y.H., 2004. Source contributions to ambient VOCs and CO at a rural site in eastern China. Atmospheric Environment. 38: 4551-4560.

Harrison, R. and Roger, P., 1986. Hand Book of Air Pollution Analysis, Chapman \& Hall, New York, USA.

Hellen, H., Hakola H. and Laurila, T., 2003. Determination of source contributions of NMHCs in Helsinki $\left(60^{\circ} \mathrm{N}, 25^{\circ} \mathrm{E}\right)$ using chemical mass balance and the Unmix multivariate receptor models. Atmospheric Environment. 37: 1413-1424.

Hellen, H., Hakola, H., Pirjola, L., Laurila, T. and Pystynen, K.A., 2006. Ambient air concentrations, source profiles and source apportionment of 71 different $\mathrm{C}_{2}-\mathrm{C}_{10}$ volatile organic compounds in urban and residential areas of Finland. Environ Sci Technol. 40: 103-108.

Jorquera, H. and Rappengluck, B., 2004. Receptor modeling of ambient VOC at Santiago, Chile. Atmospheric Environment. 38: 4243-4263.

Kansal, A., 2009. Sources and reactivity of NMHCs and VOCs in the atmosphere: A review. Journal of Hazardous Materials. Article in Press. 
Kuntasal, O.O., Karman, D., Wang, D., Tuncel, S.G. and Tuncel, G., 2005. Determination of volatile organic compounds in microenvironments by multibed adsorption and short-path thermal desorption followed by gas chromatographic-mass spectrometric analysis. Journal of Chromatography A. 1099, 43-54.

Lee, S. C., Chu, M.Y., Ho, K.E., Zou, S.C. and Wang, X., 2002. Volatile organic compounds (VOCs) in urban atmosphere of Hong Kong. Chemosphere. 48: 375-382.

Liu, P.W.G., Yao, Y.C., Tsai, J.H., Hsu, Y.C., Chang, L.P. and Chang, K.H., 2008. Source impacts by volatile organic compounds in an industrial city of southern Taiwan. Science of the Total Environment. 398: 154-163.

Lung, C.H., Horng, T.J., Yu, C.S., Hsiung, L.K. and Yi, M.S., 2007. VOC concentration profiles in an ozone non-attainment area: A case study in an urban and industrial complex metroplex in southern Taiwan. Atmospheric Environment. 41: 1848-1860.

Nguyen, H.T., Kim, K.H. and Kim, M.Y., 2009. Volatile organic compounds at an urban monitoring station in Korea. Journal of Hazardous Materials. 161: 163-174.

Parra, M.A., Elustondo, D., Bermejo, R. and Santamaria, J.M., 2009. Ambient air levels of volatile organic compounds (VOC) and nitrogen dioxide $\left(\mathrm{NO}_{2}\right)$ in a medium size city in Northern Spain. Science of the Total Environment. 407: 999-1009.

Ras, M.R., Borrull, F. and Marca, R.M., 2008. Sampling and pre concentration techniques to the determination of volatile organic compounds in air samples. Trends in Analytical Chemistry. doi: 10.1016/j.trac.2008.10.009.

Ribes, A., Carrera, G., Gallego, E., Roca, X., Berenguer, M.J. and Guardino, X., 2007. Development and validation of method for air-quality and nuisance odours monitoring of volatile organic compounds using multi-sorbent adsorption and gas chromatography/mass spectrometry thermal desorption system. Journal of Chromatography A. 1140: 44-55.

Srivastava, A., 2004. Source apportionment of ambient VOCs in Mumbai city. Atmospheric Environment. 38: 6829-6843.

Song, Y., Dai, W., Shao, M., Liu, Y., Lu, S., Kuster, W. and Golden, P., 2008. Comparison of receptor models for source apportionment of volatile organic compounds in Beijing, China. Environmental Pollution. xx: 1-10.

USEPA, 1997. Compendium Method TO-17: Determination of Volatile Organic Compounds in Ambient Air Using Active Sampling onto Sorbent Tubes, EPA/625/R-96/010b, US Environmental Protection Agency, Cincinnati, $\mathrm{OH} 45268$.

Wang, P. and Zhao, W., 2008. Assessment of ambient volatile organic compounds (VOCs) near major roads in urban Nanjing, China. Atmospheric Research. 89: 289-297.

WHO, 2000. Air Quality Guidelines for Europe, WHO Regional Publications, European Series, Second edition, No. 91, WHO, Copenhagen. 